\title{
Effect of Liquid Hot Water Pretreatment on Hydrolysates Composition and Methane Yield of Rice Processing Residue
}

\author{
Lisbet Mailin López González ${ }^{1}$ (D) and Monika Heiermann ${ }^{2, *(\mathbb{D})}$ \\ 1 Centro de Estudios de Energía y Procesos Industriales (CEEPI), Universidad de Sancti Spíritus “José Martí \\ Pérez" (UNISS), Avenida de los Mártires 360, Sancti Spíritus CP 60100, Cuba; lisbetmailin1970@gmail.com \\ 2 Leibniz Institute for Agricultural Engineering and Bioeconomy, Department Technology Assessment and \\ Substance Cycles, Max-Eyth-Allee 100, 14469 Potsdam, Germany \\ * Correspondence: mheiermann@atb-potsdam.de; Tel.: +49-(0)331-5699-217
}

Citation: López González, L.M.;

Heiermann, M. Effect of Liquid Hot Water Pretreatment on Hydrolysates Composition and Methane Yield of Rice Processing Residue. Energies 2021, 14, 3254. https://doi.org/ $10.3390 /$ en14113254

Academic Editor: Biagio Morrone

Received: 26 April 2021

Accepted: 30 May 2021

Published: 2 June 2021

Publisher's Note: MDPI stays neutral with regard to jurisdictional claims in published maps and institutional affiliations.

Copyright: (c) 2021 by the authors. Licensee MDPI, Basel, Switzerland. This article is an open access article distributed under the terms and conditions of the Creative Commons Attribution (CC BY) license (https:// creativecommons.org/licenses/by/ $4.0 /)$.

\begin{abstract}
Lignocellulosic rice processing residue was pretreated in liquid hot water (LHW) at three different temperatures $\left(140,160\right.$, and $\left.180^{\circ} \mathrm{C}\right)$ and two pretreatment times (10 and $\left.20 \mathrm{~min}\right)$ in order to assess its effects on hydrolysates composition, matrix structural changes and methane yield. The concentrations of acetic acid, 5-hydroxymethylfurfural and furfural increased with pretreatment severity (log Ro). The maximum methane yield $\left(276 \mathrm{~L} \mathrm{~kg}^{-1} \mathrm{VS}\right)$ was achieved under pretreatment conditions of $180{ }^{\circ} \mathrm{C}$ for $20 \mathrm{~min}$, with a $63 \%$ increase compared to untreated biomass. Structural changes resulted in a slight removal of silica on the upper portion of rice husks, visible predominantly at maximum severity. However, the outer epidermis was kept well organized. The results indicate, at severities $2.48 \leq \log$ Ro $\leq 3.66$, a significant potential for the use of LHW to improve methane production from rice processing residue.
\end{abstract}

Keywords: anaerobic digestion; liquid hot water pretreatment; hydrothermal pretreatment; lignocellulose; silica

\section{Introduction}

Rice cultivation is carried out in 113 countries and constitutes the staple food for more than half of the world's population. Among the world's leading producers are China, India, Indonesia, Bangladesh, Vietnam, Thailand, Myanmar, Philippines, Brazil and Japan, with 439.9 million tonnes of millet-equivalent rice [1]. This is considered the third agricultural crop of global importance in terms of total cultivated area and production. According to the FAO, it is estimated that world rice production will be 760 million tons of paddy rice by 2025 , which would generate approximately 1140 million tons of crop residues [1].

Several kinds of residual biomass are produced during harvesting and processing rice: rice straw (RS), rice husk $(\mathrm{RH})$, rice dust and rice residue generated under dry conditions (RD). RS, comprising leaves and stems, is a by-product accruing when harvesting paddy. It is separated from the grains after the plants are threshed either manually or by using combine harvesters [2]. RH is the outermost hard protective covering of rice grains (rough rice or paddy), formed by hard lignocellulosic materials along with appreciable amounts of silica. These so-called hulls are separated from the grains during the milling process [2]. RD is a residual biomass obtained from the drying process and is composed of $\mathrm{RH}$, RS and in smaller proportions of broken rice grains. In Cuba, per each tonne of paddy rice, $40 \mathrm{~kg}$ of RD are generated [3]. Inappropriate management and the deficiency in adequate treatment of these residues, such as open burning, cause environmental pollution and wastes untapped resources [4]. Thus, the increasing demand for energy and fuel is encouraging research regarding the use of locally available residual biomass feedstock as a sustainable source of energy in Cuba.

The conversion of RD to methane as a renewable energy carrier by anaerobic digestion can alleviate, to a certain extent, both energy and environmental problems [5]. A previous 
work on biogas production from RD determined a methane yield of $0.168 \mathrm{~m}^{3} \mathrm{~kg}^{-1} \mathrm{VS}$ under mesophilic conditions, with a 0.46 conversion efficiency [6]. Within this study, the hydrolysis of RD was considered the key-rate limiting step due to its complex lignocellulosic structure (34.3\% crude fibre and $10.4 \%$ lignin), which is resistant to enzymatic action. A pretreatment to enhance hydrolysis is therefore essential to improve the biodegradability of RD.

Currently, various pretreatment technologies, including physical, chemical, physicochemical, and biological approaches, have been introduced to lignocellulosic feedstocks prior to conversion [7]. Depending on the chosen pretreatment, a few disadvantages are associated with the additional process step: high energy demand, chemical or/and water requirements, formation of inhibitory compounds, need for a post-treatment step to recover solvents, neutralization of the pretreated biomass prior to anaerobic digestion and extra treatment times [8].

However, LHW pretreatment, also known as hydrothermal pretreatment (HP), offers several advantages: no need for particle size reduction or the dispensation of adding chemicals and, hence, no necessity for anti-corrosion reactors, meaning self-sufficiency in terms of thermal requirements (using heat from the CHP), and by working at high temperatures, pathogens are eliminated [9].

During the LHW step, lignocellulosic biomass is exposed to high temperature $\left(120-230^{\circ} \mathrm{C}\right)$ under subcritical conditions [10], with pretreatment times between 2 min and $6 \mathrm{~h} \mathrm{[11,12].}$ This setting is efficient in penetrating the biomass, which causes the hydrolysis of hemicellulose into soluble oligosaccharides. The reaction is catalysed by hydronium ions formed by the autoionization of water, as well as acetic acid produced from O-acetyl groups [13].

Although LHW pretreatment shows numerous advantages in terms of organic substrates digestibility, a high-temperature pretreatment or extended thermal pretreatment can produce inhibitory compounds such as furfural and 5-hydroxymethylfurfural (HMF) [9]. In addition, subjecting sugars and amino acids containing compounds to high temperature in an aqueous medium leads to the formation of recalcitrant compounds known as melanoidines [14]. This may or may not affect the biodegradability of the substrate according to the balance obtained when considering the benefits of the complex biomass structure destruction [15]. Consequently, the temperature and time required for thermal pretreatment should be carefully determined depending on the substrates' characteristics.

LHW pretreatment has been successfully applied to hydrolyse biomass, in order to increase biogas production [12,16-19]. Antwi, et al. [16] varied the temperature and reaction times between 150 and $220^{\circ} \mathrm{C}$, and 5 and $15 \mathrm{~min}$, respectively. It was found that a low-severity ( $\log$ Ro < 3.0) HP of cocoa pods residues improved the biogas yield. This is primarily due to an increased hydrolysis of the hemicellulose fraction. However, higher severity resulted in lower biogas yield. The optimum biogas yield $\left(526 \mathrm{~L} \mathrm{~kg}^{-1} \mathrm{VS}\right.$ ) was obtained at $150{ }^{\circ} \mathrm{C}$ for $15 \mathrm{~min}$, which corresponds to a severity of 2.65. Ziemiński, et al. [17] investigated the pretreatment of sugar beet pulp carried out at temperatures ranging from 120 to $200{ }^{\circ} \mathrm{C}$ in a $600 \mathrm{~mL}$ thermostatic reactor for $20 \mathrm{~min}$. The highest cumulative methane yield observed was $503 \mathrm{~L} \mathrm{~kg}^{-1} \mathrm{VS}$ from a $160{ }^{\circ} \mathrm{C}$ pretreated pulp.

In a preliminary work, Budde, et al. [19] studied the thermobarical pretreatment $\left(140-220^{\circ} \mathrm{C}, 5 \mathrm{~min}\right)$ of solid cattle manure in a $600 \mathrm{~mL}$ thermostatic reactor. Subsequent anaerobic digestion revealed a $57 \%$ increase in cumulative methane yield for a pretreatment carried out at $160^{\circ} \mathrm{C}$, whereas at $220^{\circ} \mathrm{C}$, the abundance of inhibitors and other nondigestible substances led to lower methane yields than those observed from untreated material. Using the same reactor device, López González, et al. [12] obtained a similar increase in cumulative methane yield at $150{ }^{\circ} \mathrm{C}$ for $20 \mathrm{~min}(63 \%)$ and $175{ }^{\circ} \mathrm{C}$ for $2 \mathrm{~min}(53 \%)$ during the LHW pretreatment of sugarcane press mud. A reduction of $9 \%$ in methane yield was reported under conditions of $200^{\circ} \mathrm{C}$ for $20 \mathrm{~min}$.

In general, pretreatment temperatures ranging from 150 to $180^{\circ} \mathrm{C}$, with times between 5 and $30 \mathrm{~min}$, were most effective for by-products such as cocoa pods residues, fruit and vegetable waste, municipal sewage, sugar beet pulp, liquid cattle manure, solid cattle 
manure and sugar cane press mud. More severe conditions $\left(190^{\circ} \mathrm{C}\right.$ for $\left.30 \mathrm{~min}\right)$ were needed to reach a high conversion efficiency from pretreated poultry slaughterhouse waste [20]. Thus, recent studies have indicated that the effectiveness of LHW pretreatment varies considerably depending on the chemical compositions and structural properties of the different biomass materials, as well as on the experimental conditions applied (heating time, temperature, pretreatment time and reactor type).

However, to the best of our knowledge, this is the first study which focuses on the impact of LHW pretreatment on RD's biodegradability. There are only a few results available that address exclusively single components such as straw or husks. The amenability of the lignocellulosic and silicified structure of available Cuban RD to LHW pretreatment with regard to methane production remains unclear. Therefore, there is a need of knowledge which could assist in determining the optimal treatment conditions for causing maximum hydrolysis while avoiding inhibitory compounds to increase conversion efficiency.

The objective of this study was (i) to evaluate the influence of the time and temperature of LHW treatment on the hydrolysates composition, matrix structural changes and methane yield (ii) to promote the pretreatment characteristics and biomethanisation performance of RD for tapping locally available residual biomass for renewable energy carrier production. Based on this objective, RD was pretreated in LHW at three different temperatures (140, 160 and $180^{\circ} \mathrm{C}$ ) and two pretreatment times $(10$ and $20 \mathrm{~min})$ in order to assess its effects on hydrolysates composition (volatile fatty acids, HMF and furfural), as well as matrix structural changes (SEM images) and methane yield.

\section{Materials and Methods}

\subsection{Substrate}

The RD was obtained from rice harvested in mid-summer of 2018 at the Cuban Rice Company 'Sur del Jíbaro' in Sancti Spíritus, Cuba (Figure 1). Subsequently, it was air-transported to Germany in sealed plastic bags and stored at room temperature until use.

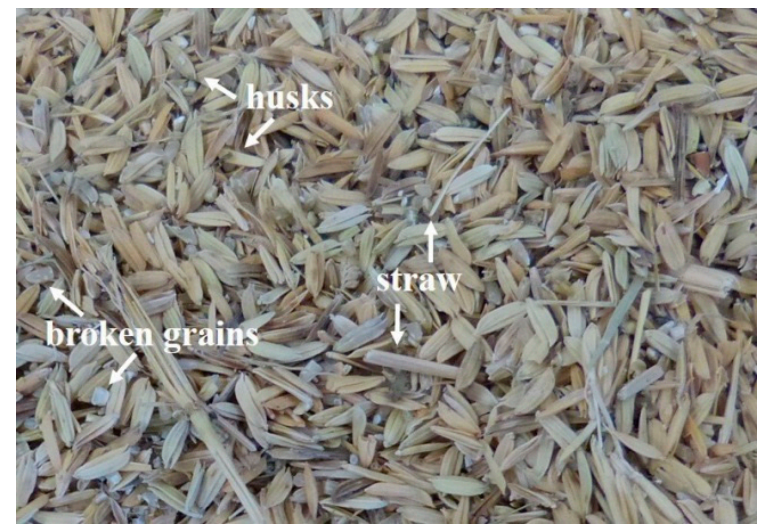

Figure 1. Photo of rice processing residue obtained in 2018 at the Rice Company 'Sur del Jíbaro' in Sancti Spíritus, Cuba. Proportion (in \%weight) of the by-products: straw $1 \%$, husk $54 \%$, broken grains $44 \%$.

\subsection{Analytical Methods}

Total solids (TS) and volatile solids (VS) contents were measured by oven drying at $105{ }^{\circ} \mathrm{C}$ and ashing the dried sample at $550{ }^{\circ} \mathrm{C}$ according to standard procedures [21].

To determine the $\mathrm{pH}$ value of solid sample, $10 \mathrm{~g}$ of rice processing residue was homogenized with $100 \mathrm{~mL}$ of distilled water. Pretreated samples from the liquid fraction were directly analysed by applying the measuring electrode Sen Tix 41 (WTW, Weilheim, Germany). Elemental analysis (C, H, N and S) was quantified using an elemental analyser (vario EL, Elementar Analysensysteme GmbH, Hanau, Germany), applying the DUMAS combustion method [21]. Elemental oxygen content was calculated by subtracting the 
measured weight percentages of $\mathrm{C}, \mathrm{H}, \mathrm{N}$ and $\mathrm{S}$ from the dry matter. Crude protein was calculated as 6.25 times the elemental nitrogen content.

The neutral detergent fibre (NDF), acid detergent fibre (ADF) and acid detergent lignin (ADL) were determined according to Van Soest, et al. [22] using the Ankom2000 Fibre Analyser system and filter bag technology (Ankom Technology Corp., Macedon, NY, USA). Hemicellulose and cellulose contents were calculated as the difference between NDF and $\mathrm{ADF}$, and ADF and ADL, respectively. Structural changes were determined using scanning electron microscopy (SEM) according to Kaplonek and Nadolny [23]. Natural specimens were visualized with the desktop microscope Phenom Pro-X (Phenom-World, Netherlands) on a charge reduction holder operated with a beam voltage of $5 \mathrm{kV}$. Therefore, dry solid specimens were mounted on aluminium stubs using a conductive, double-sided tape. The provided software Phenom ${ }^{\mathrm{TM}}$ Pro Suite was applied for image acquisition, processing and analysis.

The liquid fraction was used to determine volatile fatty acids (VFA) and degradation products (HMF and furfural). Analyses of VFA (acetic, propionic, iso-butyric, butyric, iso-valeric, valeric and caproic acids) were conducted using a gas chromatograph (Agilent Technologies Inc., Santa Clara, CA, USA) equipped with a PERMABOND_FFAP capillary column ( $30 \mathrm{~m} \times 0.32 \mathrm{~mm}$, film thickness of $0.5 \mu \mathrm{m}$, Machery-Nagel GmbH \& Co KG, Düren, Germany) and a flame ionisation detector. The detector temperature was set at $220{ }^{\circ} \mathrm{C}$. For split injection $\left(1 \mu \mathrm{L}\right.$, split 1:20) at $200{ }^{\circ} \mathrm{C}$, the sample was homogeneously mixed with nitrogen (flow rate of $50 \mathrm{~mL} \cdot \mathrm{min}^{-1}$ ) as the carrier gas by using a $4 \mathrm{~mm}$ glass liner with silanized glass wool. The following oven temperature program was applied: initial temperature of $80^{\circ} \mathrm{C}$ (hold time $0 \mathrm{~min}$ ); heating rate of $15^{\circ} \mathrm{C} \mathrm{min}^{-1}$ to $210{ }^{\circ} \mathrm{C}$, hold for $1 \mathrm{~min}$. The measurement procedure was calibrated by external standards. For this purpose, 4 standard solutions of different concentrations (ranges: acetic acid 0.5 to $8.0 \mathrm{~g} \cdot \mathrm{L}^{-1}$; propionic acid 0.2 to $6.4 \mathrm{~g} \cdot \mathrm{L}^{-1}$; butyric 0.25 to $2.0 \mathrm{~g} \cdot \mathrm{L}^{-1}$; iso-butyric, iso-valeric, valeric and caproic acid 0.1 to $0.8 \mathrm{~g} \cdot \mathrm{L}^{-1}$ ) were prepared for each analyte and injected into the GC. The analyte-specific factor was determined from the peak area with the software via start and stop time, as well as maximum height. Furfural and HMF were measured using a Dionex ICS 3000 (Thermo Fisher Scientific Inc., Bartlesville, OK, USA) equipped with a Eurospher $\mathrm{C} 18$ column $(150 \times 4 \mathrm{~mm}$, pore size of $100 \AA$, endcapped, including pre-column, Knauer GmbH \& Co KG, Auerbach, Germany) and a Dionex Series VWD UV/VIS-detector at $280 \mathrm{~nm}$ (Thermo Fisher Scientific Inc., Bartlesville, OK, USA). Ultrapure water (A) and a degassed 1:1 volumetric mixture of ultrapure water and acetonitrile (B) were used in a multistep gradient. The flow rate was maintained at $1 \mathrm{~mL} \mathrm{~min}{ }^{-1}$. The autosampler temperature was $15^{\circ} \mathrm{C}$; the column and detector temperature were $23^{\circ} \mathrm{C}$. Evaluation of the resulting chromatograms was performed with Chromeleon software (Thermo Fisher Scientific Inc., Bartlesville, OK, USA). The calibration of the measurement method was carried out via an external standard and calibration function, as described in Wirth, et al. [24].

\subsection{Pretreatment Conditions}

RD pretreatment assays were conducted in a $600 \mathrm{~mL}$ Mini Reactor System, Model number 4568 (Parr Instruments, Moline, IL, USA) [19]. A $50 \mathrm{~g}$ RD sample was mixed with $350 \mathrm{~g}$ of deionized water, with a liquid-to-solid ratio of 7.5, and was heated at several temperatures $\left(140,160\right.$ and $\left.180{ }^{\circ} \mathrm{C}\right)$, under constant stirring ( $\left.380 \mathrm{rpm}\right)$, and for different reaction times (10 and $20 \mathrm{~min}$ ) with a heating rate of $6.5^{\circ} \mathrm{C} \mathrm{min}^{-1}$. The pressure values employed were equivalent to the temperature-specific saturated water vapour pressure. Experiments were performed in triplicate.

After pretreatment time completion, the heater was removed and the reactor was cooled down to less than $50{ }^{\circ} \mathrm{C}$ by immersion into water at room temperature. The pretreated RD sample was taken out of the reactor and stored in sealed containers at $4{ }^{\circ} \mathrm{C}$. A subsample was used to separate the liquid and solid fractions by centrifugation at $6000 \mathrm{rpm}$ for $15 \mathrm{~min}$. The liquid fraction (supernatant) was stored at $-20^{\circ} \mathrm{C}$ for subsequent analysis. 
The severity factor Ro was determined for each experimental variant. This parameter quantifies the hydrothermal pretreatment-combined effect of time and temperature on the matrix, and it is defined by Equation (1).

$$
\operatorname{Ro}=t \cdot e^{\frac{T_{r}-T_{b}}{14.75}}
$$

$\mathrm{t}$ is the pretreatment time in $\min , \mathrm{T}_{\mathrm{b}}$ is the base temperature $\left(10{ }^{\circ} \mathrm{C}\right), \mathrm{T}_{\mathrm{r}}$ is the pretreatment temperature in ${ }^{\circ} \mathrm{C}$, and 14.75 is the conventional energy of the activation factor assuming a hydrolytic overall reaction, and the overall conversion is of first-order kinetics [25].

\subsection{Anaerobic Digestion}

\subsubsection{Biochemical Methane Potential (BMP) Test}

The BMP of untreated and pretreated RD was determined at $37.5^{\circ} \mathrm{C}$ for 30 days, according to VDI 4630 [26]. Batch experiments were carried out in lab-scale $2 \mathrm{~L}$ reactors. Once daily, reactors were shaken manually. In order to guarantee the homogeneity of each triplicate of pretreated RD, it was separated into solid and liquid fractions via centrifugation. The liquid and solid fractions were weighed, and their proportions were calculated. Consequently, each reactor was fed with $100 \mathrm{~g}$ of pretreated RD. The batches were carried out at substrate/inoculum ratios of $0.5-0.7$ (g VS/g VS). The inoculum consisted of digestate of previously completed batch digestion tests with crop materials and was characterized by $2.69 \%$ TS and $71.69 \%$ VS. Six batch assays and controls, including inoculum (blank reactor), untreated $\mathrm{RD}$ (control reactor) and cellulose (reference reactor), were performed in triplicate.

The biogas production volume was measured by liquid displacement (saturated $\mathrm{NaCl}$ solution; $\mathrm{pH}$ 5). The volume was normalized to standard conditions comprising dry gas, a temperature of $0{ }^{\circ} \mathrm{C}$ and a pressure of $1013 \mathrm{hPa}$ [26], and it is reported as the statistical mean for each set of triplicates. The biogas composition (methane, carbon dioxide, oxygen and hydrogen sulphide content) was measured during the batch digestion using a gas analyser BM5000 (Geotechnical Instruments Ltd, Leamington Spa, UK). The methane yield is given in $\mathrm{L}$ per $\mathrm{kg}$ of fed volatile solids content $\left(\mathrm{L} \mathrm{kg}^{-1} \mathrm{VS}\right)$.

The theoretical methane yield for untreated biomass $\left(y_{\text {theo }}\right)$ was calculated using Buswell's equation [27] modified by O'Rourke [28] (Equation (2)). The reaction associated is represented by Equation (3) [28]. Knowing the experimental methane yield ( $y_{\text {exp }}$ ), the overall efficiency of the anaerobic process $(\eta)$ can be calculated using Equation (4).

$$
y_{\text {theo }}=\frac{(4 \cdot a+b-2 \cdot c-3 \cdot d) \cdot 22400}{(12 \cdot a+b+16 \cdot c+14 \cdot d) \cdot 8}
$$

$$
\begin{gathered}
\mathrm{C}_{a} \mathrm{H}_{b} \mathrm{O}_{c} \mathrm{~N}_{d}+\left(a-\frac{b}{4}-\frac{c}{2}+\frac{3 d}{4}\right) \mathrm{H}_{2} \mathrm{O} \rightarrow\left(\frac{a}{2}-\frac{b}{8}+\frac{c}{4}+\frac{3 d}{8}\right) \mathrm{CO}_{2}+\left(\frac{a}{2}+\frac{b}{8}-\frac{c}{4}-\frac{3 d}{4}\right) \mathrm{CH}_{4}+d \mathrm{NH}_{3} \\
\eta=\frac{y_{\text {exp }}}{y_{\text {theo }}} \cdot 100
\end{gathered}
$$

\subsubsection{Kinetic Models}

In this study, both the Hill-modified model (Equation (5)) and the modified Gompertz equation (Equation (6)) were used to evaluate the methane production kinetics of the BMP tests.

$$
\begin{gathered}
y_{(t)}=y_{\max } \frac{t^{b}}{c^{b}+t^{b}} \\
y_{(t)}=y_{\max } \exp \left[-\exp \left(\frac{R_{m} e}{y_{\max }}(\lambda-t)+1\right)\right]
\end{gathered}
$$


where $y_{(t)}$ is the cumulative methane yield ( $\left.\mathrm{L} \mathrm{kg}^{-1} \mathrm{VS}\right), y_{\max }$ is the ultimate methane yield taken as the residence time tends to infinity, $\lambda$ is the lag time (days), $R_{m}$ is the maximum methane production rate $\left(\mathrm{L} \mathrm{kg}^{-1} \mathrm{VS} \mathrm{d}^{-1}\right), \mathrm{t}$ is the time (days), and $b$ and $c$ are equation coefficients. The models implementations, as well as the numeric parameters identification, were performed by a nonlinear regression analysis (Statgraphics Centurion XVI.2, Statpoint Technologies, Inc., Orlean, VA, USA).

One-way ANOVA (analysis of variance) was used to test significant differences in mean values for methane yields from raw material, and from pretreated RD. The statistical means between pretreatment pairs were compared using a test of multiple ranks (Duncan's test). Data normality and homogeneity of variances were determined using the Kolmogornov-Smirnov and the Fischer tests, respectively. The datasets were analysed using Statgraphics Centurion XVI.2 with a confidence interval of $95 \%$.

\section{Results and Discussion}

\subsection{Substrate Composition}

The main characteristics of the RD are presented in Table 1 . The substrate depicts a TS value of $93.88 \%$ and relatively low VS concentration of $61.28 \%$ of TS, owed to the high proportion of silica according to reports found in the literature $[29,30]$.

Table 1. Physical and chemical properties of the rice processing residue.

\begin{tabular}{ccc}
\hline Parameters & Units & Average Values * \\
\hline pH & \% FM & 6.07 \\
TS105 & \%TS & 93.88 \\
VS & \%TS & 61.28 \\
Ash & \%TS & 38.72 \\
Crude protein & \%TS & 7.85 \\
Hemicellulose & \%TS & 18.31 \\
Cellulose & \%TS & 19.09 \\
Lignin & \%TS & 6.97 \\
C & \%TS & 34.32 \\
H & \%TS & 3.34 \\
N & \%TS & 1.26 \\
S & & 0.10 \\
C/N & & 27.33 \\
\hline
\end{tabular}

* Double determination. Coefficient of variation was under $3 \%$ for all parameters.

The RD shows a fibre content of $44.36 \%$ with a higher proportion of cellulose and hemicellulose. The elemental composition determined was very similar to the content of $C$, $\mathrm{N}$ and $\mathrm{S}$ reported by Contreras, et al. [6]. However, lignin was found in lower quantities than in Contreras, et al. [6], which may be caused by a lower proportion of rice husk in the $\mathrm{RD}$ used for the current investigation.

\subsection{Effect of LHW Pretreatment on Hydrolysates Composition}

The effect of LHW pretreatment on the hydrolysates composition contained in the liquid fraction is summarized in Table 2.

Acetic and propionic acids were the only volatile acids found. Acetic acid was produced up to 11 times more than propionic acid. The presence of acetic acid was raised by increasing the pretreatment severity, with a marked increase when log Ro $>3.07$ (Figure 2). Its formation as a function of $\log$ Ro fitted well $\left(R^{2}=0.98\right)$ with a quadratic model (Equation (7)). For $\log$ Ro $\leq 3.07$, corresponding to temperatures of 140 and $160{ }^{\circ} \mathrm{C}$, the acetic acid concentration went from 0.45 to $0.79 \mathrm{~g} \mathrm{~L}^{-1}$ (Figure 2). A maximum value of $2.76 \mathrm{~g} \mathrm{~L}^{-1}$ was determined for $\log \mathrm{Ro}=3.66\left(180^{\circ} \mathrm{C}\right.$ for $\left.20 \mathrm{~min}\right)$. 
Table 2. Chemical composition of liquid fraction from pretreated rice processing residue.

\begin{tabular}{|c|c|c|c|c|c|c|c|c|}
\hline $\begin{array}{c}\mathrm{T} \\
\left({ }^{\circ} \mathrm{C}\right)\end{array}$ & $\begin{array}{c}t \\
(\min )\end{array}$ & $\log$ Ro & $\begin{array}{l}\text { Residual } \\
\text { RD (\%) }\end{array}$ & $\mathrm{pH}$ & $\begin{array}{l}\text { Acetic Acid } \\
\qquad\left(g^{-1} L^{-1}\right.\end{array}$ & $\begin{array}{l}\text { Propionic Acid } \\
\qquad\left(\mathrm{g} \mathrm{L}^{-1}\right)\end{array}$ & $\begin{array}{c}\mathrm{HMF} \\
\left(\mathrm{mg} \mathrm{L}^{-1}\right)\end{array}$ & $\begin{array}{l}\text { Furfural } \\
\left(\mathrm{mg} \mathrm{L} \mathrm{L}^{-1}\right)\end{array}$ \\
\hline 140 & 10 & 2.18 & 61 & 6.02 & 0.45 & 0.10 & n.d. & n.d. \\
\hline 140 & 20 & 2.48 & 63 & 5.88 & 0.52 & 0.09 & n.d. & n.d. \\
\hline 160 & 10 & 2.77 & 59 & 5.78 & 0.65 & 0.13 & 10.53 & 5.58 \\
\hline 160 & 20 & 3.07 & 55 & 5.59 & 0.79 & 0.12 & 7.91 & 12.08 \\
\hline 180 & 10 & 3.36 & 37 & 4.99 & 1.90 & 0.24 & 22.44 & 69.58 \\
\hline 180 & 20 & 3.66 & 32 & 4.64 & 2.76 & 0.26 & 53.47 & 149.40 \\
\hline
\end{tabular}

n.d. not detected. Double determination. Coefficient of variation was under $3 \%$ for all parameters. Residual RD calculated in \% from solid fraction of RD pretreated.

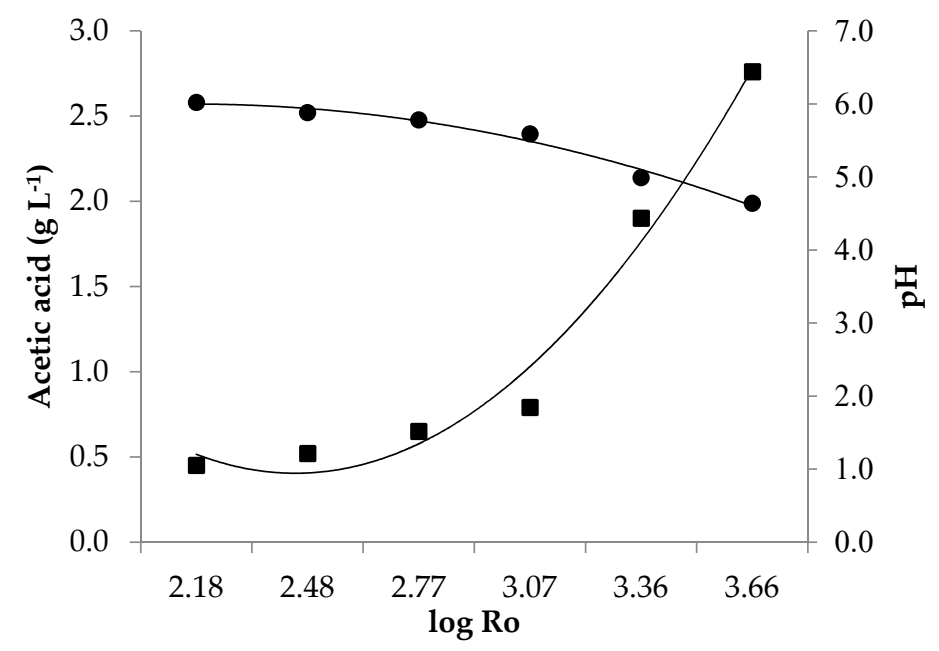

Figure 2. Composition of acetic acid $(\bullet)$ and $\mathrm{pH}(\bullet)$ according to the pretreatment severity $(\log \mathrm{Ro})$.

A similar performance was observed by López González, et al. [12], who reported acetic acid concentrations of $0.4 \mathrm{~g} \mathrm{~L}^{-1}$ for $\log \mathrm{Ro}=2.17\left(150^{\circ} \mathrm{C}\right.$ for $\left.5 \mathrm{~min}\right)$ and $1.6 \mathrm{~g} \mathrm{~L}^{-1}$ for $\log \mathrm{Ro}=2.49\left(175^{\circ} \mathrm{C}\right.$ for $\left.2 \mathrm{~min}\right)$. Acetic acid (and other organic acids) is the by-product of hemicellulose O-acetyl groups (glucuronide conjugates) hydrolysis [13]. $\mathrm{H}^{+}$ions from those acids lowered the $\mathrm{pH}$ from 6.02 to 4.64 (Table 2 and Figure 2).

Furan compounds (HMF and furfural) were found in the liquid fraction, formed at 160 and $180^{\circ} \mathrm{C}$ with a marked increase at $180^{\circ} \mathrm{C}$. The maximum furfural concentration of $149.40 \mathrm{mg} \mathrm{L}^{-1}$ determined (equivalent to $1.26 \mathrm{mg} \mathrm{g}^{-1} \mathrm{TS}$ ) was greater than that reported by Wang, et al. [18] for pretreated RS at $180^{\circ} \mathrm{C}$ for $15 \mathrm{~min}\left(0.6 \mathrm{mg} \mathrm{g}^{-1} \mathrm{TS}\right)$. The maximum furfural production $\left(2800 \mathrm{mg} \mathrm{L}^{-1}\right)$ for pretreated RS was demonstrated at higher temperature $\left(200{ }^{\circ} \mathrm{C}\right.$ for both 10 and $\left.30 \mathrm{~min}\right)$, corresponding to a complete or nearly complete degradation of xylose and arabinose [31]. In the case of HMF concentrations, a maximum value of $53.47 \mathrm{mg} \mathrm{L}^{-1}$ at $\log \mathrm{Ro}=3.66\left(180^{\circ} \mathrm{C}\right.$ for $\left.20 \mathrm{~min}\right)$ was observed (Figure 3$)$. This agrees well with results described by $\mathrm{Wu}$, et al. [30], who found low concentrations of HMF for pretreated $\mathrm{RH}$ at $\log \mathrm{Ro}=3.35\left(180^{\circ} \mathrm{C}, 10 \mathrm{~min}\right)$ and $\log \mathrm{Ro}=3.65\left(190{ }^{\circ} \mathrm{C}, 10 \mathrm{~min}\right)$. 


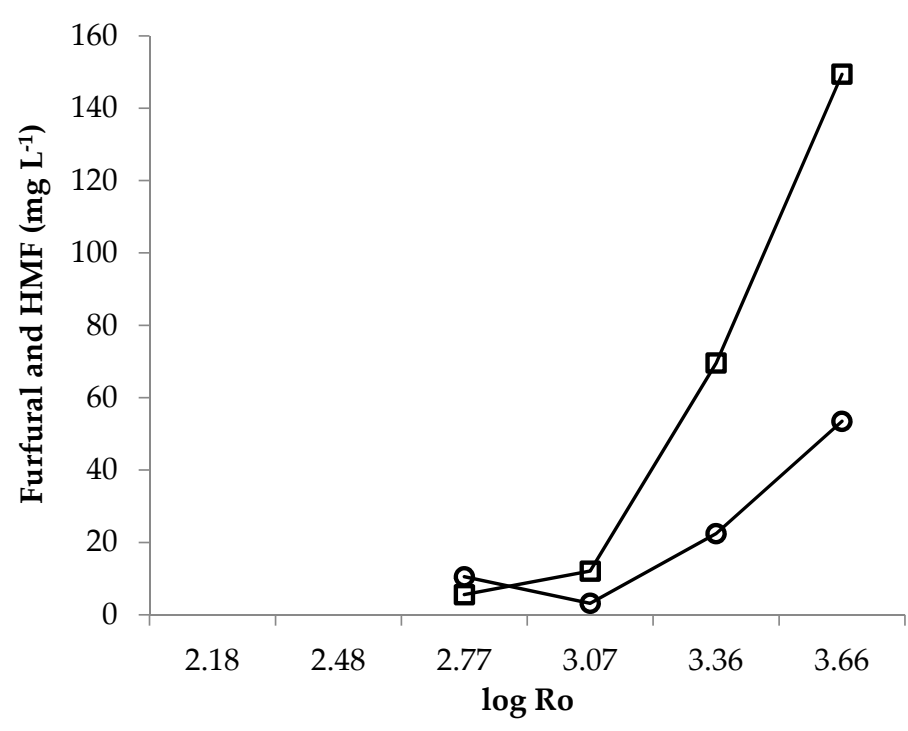

Figure 3. Concentration of HMF $(\bigcirc)$ and furfural $(\square)$ according to the pretreatment severity (log Ro). Not detected for $\log$ Ro $=0.00, \log$ Ro $=2.18$ and $\log$ Ro $=2.48$.

In another study carried out at several temperatures $\left(90,150,180\right.$ and $\left.210{ }^{\circ} \mathrm{C}\right), \mathrm{HMF}$ was not detected for the pretreated RS [18]. Furfural is obtained by pentose degradation, while HMF is a hexose dehydration product. Therefore, a lower concentration of HMF is expected as cellulose solubilisation and consequent glucose formation are limited [9]. HMF and furfural are toxic and known to be methanogenic inhibitors; thus, they are undesirable products for the following anaerobic digestion process. Their maximum concentration found in this study is below the limits previously reported [32].

\subsection{Effect of LHW Pretreatment on Structural Changes}

The structural changes of RD's most abundant component, the RH, were studied by SEM. $\mathrm{RH}$ is composed approx. $20 \%$ of silicon dioxide nanoparticles. The remaining part is an organic phase, mainly cellulose, hemicellulose and lignin [33].

The SEM images of the outer surface of untreated and pretreated RH are shown in Figure 4. The outer epidermis of RH is organized well and has a corrugated ridged structure (Figure $4 \mathrm{a}-\mathrm{c}$ ). It appears to be highly undulated due to the presence of regularly spaced protrusions which contain high concentrations of silica, as previously reported $[29,33]$. The outer surface also contains papillae and hairs.

SEM images reveal that the surface structure of the RH did not change significantly via pretreatment (Figure $4 \mathrm{~d}-1$ ). At 140 and $160{ }^{\circ} \mathrm{C}$, some materials were melted and resolidified on the surface. However, when the temperature was increased to $180^{\circ} \mathrm{C}$, these materials must have been transferred into the liquid phase as the surface is cleanly visible after the LHW pretreatment. The domes containing silica were broken at the maximum severity $\left(180{ }^{\circ} \mathrm{C}\right.$ for $\left.20 \mathrm{~min}\right)$ and the $\mathrm{RH}$ was softer and flexible to the touch.

Previous studies described much lower values of silica in the regions where the domes were broken [29]. According to Fijalkowski, et al. [33], amorphous silica nanoparticles form layers on the surface of the $\mathrm{RH}$, acting as a physical barrier against enzyme attack. Ang, et al. [34] assessed the impact of various pretreatment reagents $\left(\mathrm{NaOH}, \mathrm{Ca}(\mathrm{OH})_{2}, \mathrm{H}_{2} \mathrm{SO}_{4}\right.$, $\mathrm{HCl}, \mathrm{H}_{3} \mathrm{PO}_{4}, \mathrm{CH}_{3} \mathrm{COOH}$ and $\mathrm{HNO}_{3}$ ) on the structural changes of $\mathrm{RH}$. The comprehensive structural characterization studies that involved Fourier transform infrared spectroscopy (FT-IR), SEM and Brunauer-Emmett-Teller (BET) surface area determination showed that the pretreated RH consisted mainly of cellulose and lignin. Compared to untreated RH, pretreated $\mathrm{RH}$ possessed an increased pore size and pore volume, which are expected to be beneficial for fungal growth during fermentation. 


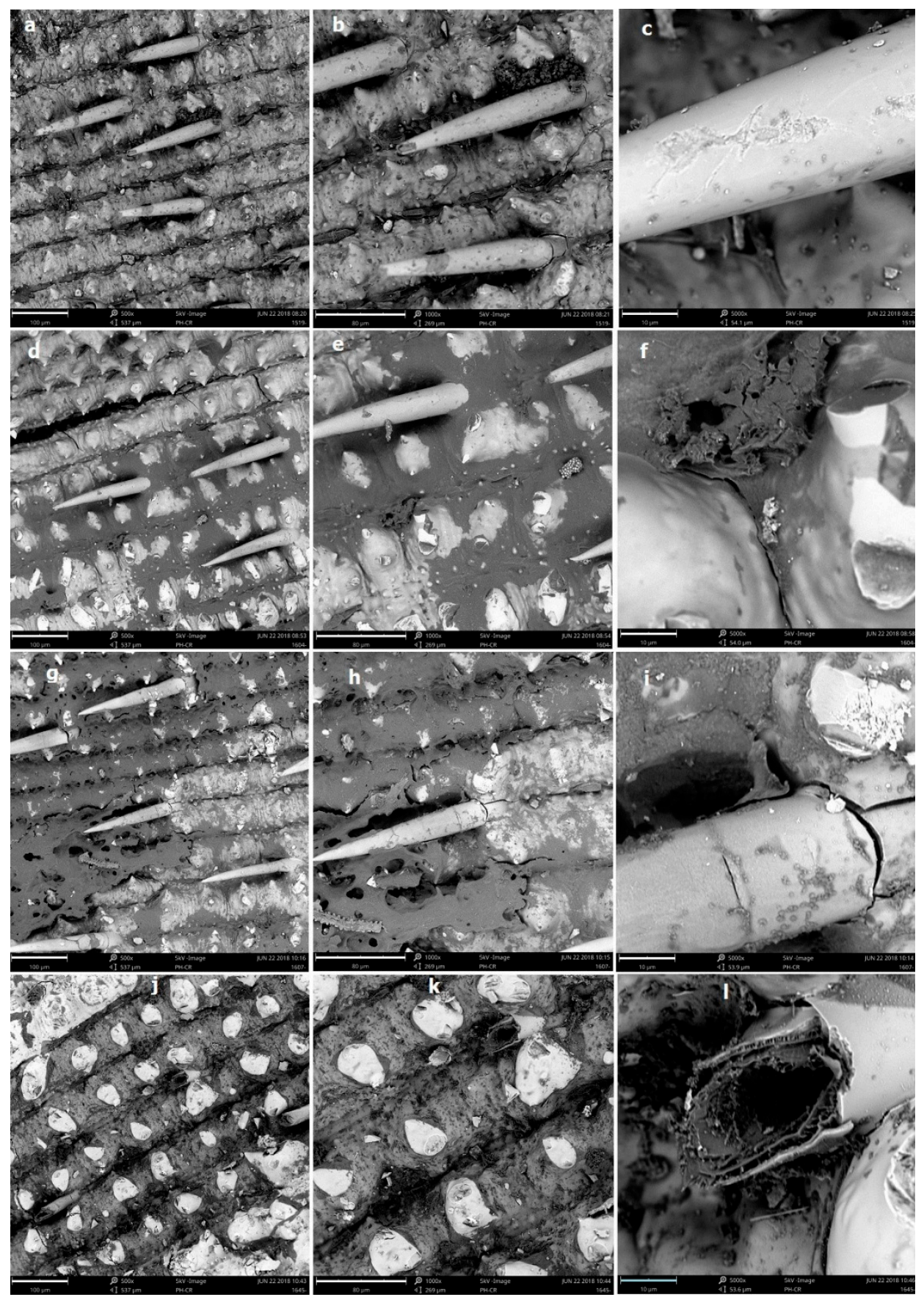

Figure 4. SEM images for untreated $(\mathbf{a}-\mathbf{c})$ and pretreated $\mathrm{RD}\left(140{ }^{\circ} \mathrm{C} \_20 \mathrm{~min}(\mathbf{d}-\mathbf{f}), 160{ }^{\circ} \mathrm{C} \_20 \mathrm{~min}\right.$ $(\mathbf{g}-\mathbf{i}), 180{ }^{\circ} \mathrm{C} \_20 \mathrm{~min}(\mathbf{j}-\mathbf{l})$ ). 3adgj (magnification $=500$ and bar $\left.=100 \mu \mathrm{m}\right)$, 3behk (magnification $=100$ and bar $=80 \mu \mathrm{m})$, 3cfil (magnification $=5000$ and bar $=10 \mu \mathrm{m})$.

The potential application of three ionic liquids in the pretreatment of rice husk was studied via structural analyses [35]. The dissolution of RH conducted with 1-ethyl-3methylimidazolium acetate at $100^{\circ} \mathrm{C}$ for $20 \mathrm{~h}$ caused the most severe swelling on the surface structure, and this pretreatment also resulted in the highest amount of regenerated cellulose.

The untreated RH was intact and showed a smooth surface, while the surface of RH residues appeared to be uneven and cracked. In another study, Ullah, et al. [36] pretreated $\mathrm{RH}$ waste using ultrasonic-assisted ionic liquids technology. The untreated RH sample was found to be smooth and regular in shape, while swelling and porosity developed in the structure of the treated sample. It is expected that by removing some of the silica during 
bioconversion, the RH will be more accessible to digestive enzymes or microorganisms. Further studies on the role of silica and the effect of its removal are required.

\subsection{Effect of LHW Pretreatment on Methane Yield}

Figure 5 reveals the effect of pretreatment on the cumulative methane yield produced from RD. The untreated RD showed a cumulative methane yield of $164 \mathrm{~L} \mathrm{~kg}^{-1} \mathrm{VS}$, which is comparable to that reported by Contreras, et al. [6].

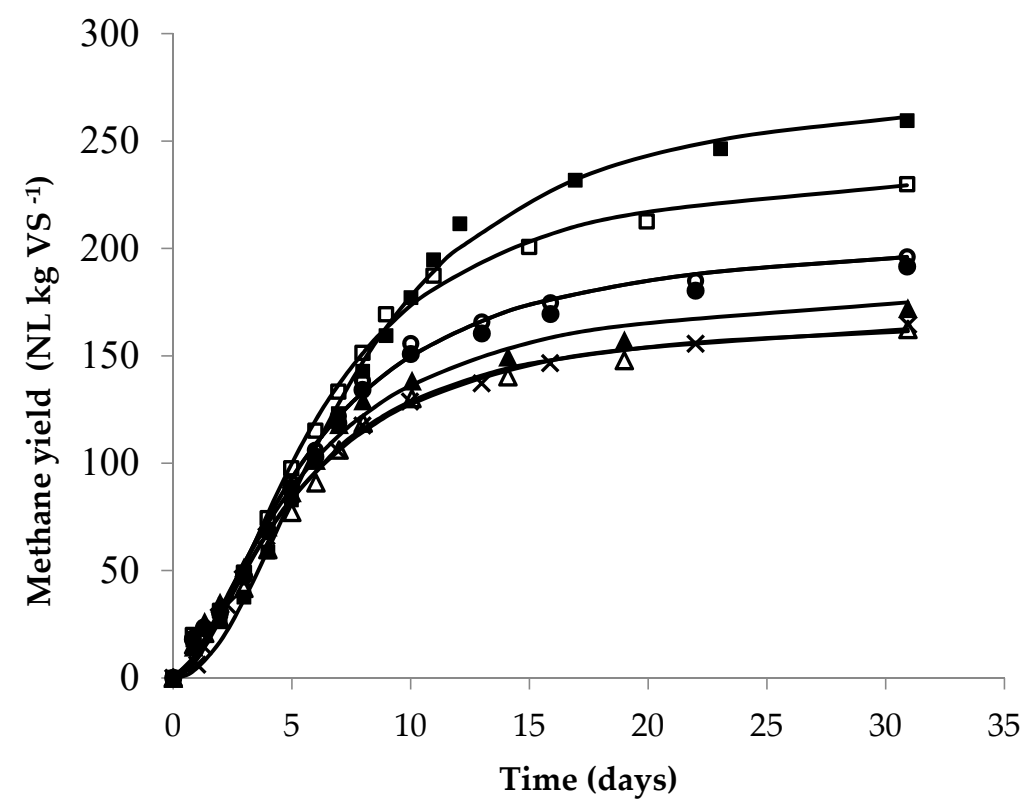

Figure 5. Cumulative methane production for untreated and pretreated rice processing residue. Untreated (x), $140{ }^{\circ} \mathrm{C} \_10 \mathrm{~min}(\Delta), 140{ }^{\circ} \mathrm{C} \_20 \mathrm{~min}(\boldsymbol{\Delta}), 160{ }^{\circ} \mathrm{C} \_10 \mathrm{~min}(\bigcirc), 160{ }^{\circ} \mathrm{C} \_20 \mathrm{~min}(\bullet)$, $180^{\circ} \mathrm{C} \_10 \mathrm{~min}(\square), 180^{\circ} \mathrm{C} \_20 \mathrm{~min}(\mathbf{\bullet})$. Hill model (lines).

Most of the LHW pretreatment conditions applied at RD increased the methane yield with significant differences compared with the untreated RD, ranging from 185 to $276 \mathrm{~L} \mathrm{~kg}^{-1}$ VS. Only the variant with the lowest pretreatment severity $(\log \mathrm{Ro}=2.48$, corresponding to a temperature of $140{ }^{\circ} \mathrm{C}$ for $10 \mathrm{~min}$ (Table 3), displayed no methane yield increase. The methane concentration determined was similar for untreated and pretreated RD (49-51\%).

Table 3. Experimental and ultimate methane yield, conversion efficiency, maximum methane production rate and lag time for untreated and pretreated rice processing residue.

\begin{tabular}{|c|c|c|c|c|c|c|}
\hline $\log (\mathrm{Ro})$ & $\begin{array}{c}y_{\exp } \\
\left(\mathrm{L} \mathrm{CH}_{4} \mathrm{~kg}^{-1} \mathrm{VS}\right)\end{array}$ & $\% \mathrm{CH}_{4}$ & $\eta(\%)$ & $\begin{array}{c}y_{\max } \\
\left(\mathrm{L} \mathrm{CH}_{4} \mathrm{~kg}^{-1} \mathrm{VS}\right)\end{array}$ & $\begin{array}{c}R_{m} \\
\left(\mathrm{~L} \mathrm{CH}_{4} \mathrm{~kg}^{-1} \mathrm{VS} \mathrm{d}^{-1}\right)\end{array}$ & $\begin{array}{c}\lambda \\
\text { (Days) }\end{array}$ \\
\hline 0.00 & $164^{\mathrm{e}} \pm 6.60$ & 50.63 & 40 & $169^{\mathrm{e}} \pm 6.99$ & $18.06^{\mathrm{c}} \pm 0.74$ & $0.52^{b c} \pm 0.01$ \\
\hline 2.18 & $162^{\mathrm{e}} \pm 6.06$ & 49.62 & 39 & $171^{\mathrm{e}} \pm 5.23$ & $17.00^{\mathrm{d}} \pm 0.25$ & $0.47^{\mathrm{cd}} \pm 0.05$ \\
\hline 2.48 & $167^{\mathrm{d}} \pm 6.53$ & 50.88 & 40 & $185^{\mathrm{d}} \pm 4.49$ & $18.51^{\mathrm{c}} \pm 0.11$ & $0.29^{\mathrm{d}} \pm 0.08$ \\
\hline 2.77 & $196^{\mathrm{c}} \pm 1.61$ & 50.27 & 47 & $208^{c} \pm 2.20$ & $19.55^{b c} \pm 0.27$ & $0.46^{\mathrm{cd}} \pm 0.04$ \\
\hline 3.07 & $191^{\mathrm{c}} \pm 4.59$ & 50.21 & 46 & $203^{c} \pm 5.69$ & $18.84^{b} \pm 0.05$ & $0.41^{\mathrm{cd}} \pm 0.05$ \\
\hline 3.36 & $230^{b} \pm 5.53$ & 49.60 & 55 & $240^{b} \pm 5.74$ & $22.27^{\mathrm{a}} \pm 0.65$ & $0.71^{b} \pm 0.17$ \\
\hline 3.66 & $260^{a} \pm 3.79$ & 49.12 & 63 & $276^{\mathrm{a}} \pm 4.06$ & $22.07^{\mathrm{a}} \pm 0.74$ & $1.32^{\mathrm{a}} \pm 0.23$ \\
\hline
\end{tabular}

a-e Groups with different superscripts differ $(p<0.05)$. Data expressed as mean \pm standard deviation. $y_{\text {exp }}$ : Experimental yield, $\% \mathrm{CH}_{4}$ : Methane content in the biogas, $\eta$ : overall efficiency of the anaerobic process, $y_{\max }$ : ultimate methane yield, $R_{m}$ : maximum methane production rate, $\lambda$ : lag time. 
Higher severity resulted in a higher methane yield. The maximum yield was attained at $180{ }^{\circ} \mathrm{C}$ and $20 \mathrm{~min}$, with a $63 \%$ increase compared to the untreated RD. During LHW pretreatment, most of hemicellulose is solubilized, while only a fraction of lignin is extracted and redeposited later [37]. As a result, the cellulose accessible surface area is enlarged and available for enzymatic attack [38].

Based on the analysed RD composition $\left(\mathrm{C}_{3.48} \mathrm{H}_{5.26} \mathrm{O}_{2.58} \mathrm{~N}_{0.17} \mathrm{~S}_{0.01}\right)$, a theoretical methane yield of $415 \mathrm{~L} \mathrm{CH}_{4} \mathrm{~kg}^{-1} \mathrm{VS}$ was calculated. Only $40 \%$ of this potential was achieved for untreated RD, which is in the range of 30-60\% for high particulate organic matter [37]. For the best RD pretreatment condition $\left(180{ }^{\circ} \mathrm{C}\right.$ for $\left.20 \mathrm{~min}\right)$, a theoretical methane yield of $63 \%$ was obtained, clearly demonstrating the positive effect of the pretreatment.

Similarly, Rajput, et al. [38] tested the LHW pretreatment of wheat straw at temperatures of $120,140,160$ and $180^{\circ} \mathrm{C}$, each held for $60 \mathrm{~min}$. The best biomass biomethanation was reached at $180{ }^{\circ} \mathrm{C}(\log$ Ro $=4.14)$, showing a $53 \%$ increase in comparison with untreated matter. In a recent work, Shang, et al. [39] found that a maximum methane yield $\left(202 \mathrm{~L} \mathrm{~kg}^{-1} \mathrm{VS}\right)$ was achieved after LHW pretreatment at $175^{\circ} \mathrm{C}$ for $30 \mathrm{~min}(\log \mathrm{Ro}=3.69)$, resulting in a $62.9 \%$ increase compared to untreated wheat straw. Lower severities $(1.88<\log$ Ro $<2.47)$ with temperatures between 140 and $160{ }^{\circ} \mathrm{C}$ were sufficient to obtain similar increases in methane yield from sugar cane press mud [12] and solid cattle manure [19].

The effect of LHW pretreatment on the anaerobic digestion of RD has not yet been reported. Hydrothermally pretreated RS at 90 and $180^{\circ} \mathrm{C}$ for 15 min slightly increased $(3 \%)$ the biogas yield in comparison with untreated RS [18]. The authors explained that these results were due to the acidification produced via the pretreatment during the batch test. However, according to values reported, acidification could have been caused by the high substrate/inoculum ratio used in the batch test: $35 \mathrm{~g}$ of TS $\mathrm{L}^{-1}$ (85 VS \%TS) and $15 \mathrm{~g}$ of TS L ${ }^{-1}$ (52.2 VS \%TS) for RS and inoculum loading, respectively. Higher methane yield increments for pretreated RS were obtained by Luo, et al. [40] and He, et al. [41]. Luo, et al. [40] examined the HP of RS at different temperatures ranging from 90 to $130{ }^{\circ} \mathrm{C}$ for $150 \mathrm{~min}$. Both 100 and $130{ }^{\circ} \mathrm{C}$ pretreatments presented similar methane yields of 128 and $125 \mathrm{~L} \mathrm{~kg}^{-1} \mathrm{VS}$, respectively, which, in turn, were $23 \%$ and $20 \%$ higher than those of untreated RS, respectively. He, et al. [41] observed a similar increase (23\%) during the LHW pretreatment of RS at a higher temperature and shorter time $\left(150{ }^{\circ} \mathrm{C}\right.$ for $\left.20 \mathrm{~min}\right)$.

LHW pretreatment at different temperatures $\left(170-230{ }^{\circ} \mathrm{C}\right)$ for $10 \mathrm{~min}$ resulted in a $7-31 \%$ increase in cumulative methane yield from giant reed grass [42]. Similar results were also reported by Di Girolamo, et al. [43], in which the methane yield from giant reed grass was increased by $23 \%$ after LHW pretreatment at $180{ }^{\circ} \mathrm{C}$ for $10 \mathrm{~min}$.

Even for the same type of biomass, the effectiveness of the pretreatment varied depending on different factors such as the chemical composition (cellulose, hemicellulose and lignin), type of reactor (batch and countercurrent) and pretreatment parameters (temperature, time, liquid-to-solid ratio, as well as heating and cooling time).

Regarding the reaction kinetics, $R_{m}$ values ranged from 17.00 to $22.27 \mathrm{~L} \mathrm{~kg}^{-1} \mathrm{VS} \mathrm{d}^{-1}$ (Table 3). The maximum values found at severities of 3.36 and $3.66\left(180{ }^{\circ} \mathrm{C}\right.$, for 10 and $20 \mathrm{~min}$, respectively) are related to the hydrolysis and solubilisation increase due the catalytic effect of the hydronium ions generated by acetic acid. A maximum $R_{m}$ of $49.2 \mathrm{~L} \mathrm{~kg}^{-1}$ $\mathrm{VS} \mathrm{d}^{-1}$ for pretreated wheat straw at a severity of 3.69 was reported by Shang, et al. [39]: as the severity was further increased, $R_{m}$ decreased.

The value of $\lambda$ (lag time in days) reflected the speed of the start-up stage in the anaerobic digestion process and the degree of inhibition at the initial stage. The short lag time ( $\lambda<1$ day) obtained for most of the conditions studied indicated the presence of a fast anaerobic digestion process, which is attributed to the large amount and quality of the inoculum added, well adapted to herbaceous biomass due to numerous previous batch tests, as well as the absence of inhibitors. At $180^{\circ} \mathrm{C}$ for $20 \mathrm{~min}, \lambda$ was increased to 1.32 days, possibly due to the high concentration of acids (Table 2) formed as a result of the 
pretreatment. The acids accumulation can cause an increase in the delay phase due to an imbalance between microbial groups, which affects the main metabolic route.

Similarly, He, et al. [41] reported a longer lag-phase time ( $\lambda=3.66-3.95$ days) for pretreated rice straw at $150{ }^{\circ} \mathrm{C}(0,10,20$ and $30 \mathrm{~min})$ in comparison to the untreated sample. A different behaviour was obtained by Rajput, et al. [38] by predicting a shorter lag phase ( $\lambda=3.37$ days) for pretreated wheat straw at $180{ }^{\circ} \mathrm{C}$ when compared to the variant ( $\lambda=12.69$ days). A longer lag time ( $\lambda=4.17-7.20$ days) than that of the control (1.63 days) indicated a significant inhibition [39], even when compared with the control under more severe conditions $\left(225^{\circ} \mathrm{C}\right.$ for 5,30 and $60 \mathrm{~min}$ ) than those applied in the present study. Theoretically, the inoculum activity, substrate/inoculum ratio, amount of readily degradable components in the substrate, inhibitors concentration, and initial $\mathrm{pH}$ of the influent have a marked impact on the anaerobic digestion start-up time [44].

\section{Conclusions}

The effectiveness of LHW pretreatment varies considerably depending on the chemical compositions and structural properties of the different biomass materials. This study provides data to adjust the pretreatment conditions (temperature and pretreatment time) of locally available $\mathrm{RD}$ considered as a feedstock for methane production as a renewable energy carrier. The best pretreatment conditions were found at higher severities $(\log R o=3.36$ and 3.66), but the highest increase in methane yield (63\%) compared to the untreated RD was found at $180{ }^{\circ} \mathrm{C}$ for 20 min with $276 \mathrm{~L} \mathrm{~kg}^{-1} \mathrm{VS}$. Structural changes showed a slight removal of the silica on the upper portion of the $\mathrm{RH}$, mostly visible at maximum severity. Future research should focus on the effect of prolonged pretreatment times ( $>20 \mathrm{~min})$ at $180^{\circ} \mathrm{C}$ for optimal subsequent anaerobic digestion of $\mathrm{RD}$, and the effect of the presence and the removal of silica. Recent research focuses on the recovery of silica as a biomaterial via combustion and chemical reactions [45]. The first results indicate that silica can also be obtained by anaerobic digestion of rice straw [46]. A major advantage of this approach is avoiding the emission of air pollutants and greenhouse gases, as well as the input of chemicals. So far, this promising pathway for the cascading use of biomass has not been explored in depth and needs future research.

Author Contributions: Conceptualization, methodology and validation: L.M.L.G. and M.H.; experiments, data analysis, visualization and writing-original draft: L.M.L.G.; writing-review and editing, L.M.L.G. and M.H. All authors have read and agreed to the published version of the manuscript.

Funding: This research was funded by the German Academic Exchange Service DAAD (grant no. 57378441).

Institutional Review Board Statement: Not applicable.

Informed Consent Statement: Not applicable.

Data Availability Statement: Not applicable.

Acknowledgments: L.M.L.G. was supported by a scholarship grant "Research Stays for University Academics and Scientists, 2018 provided by the German Academic Exchange Service DAAD (grant no. 57378441). The authors wish to express their appreciation to Vincent Plogsties, Anka Thoma and Jutta Venzke for their excellent technical support and Albert Hernandez-Estrada for introduction to SEM. The publication of this article was funded by the Open Access Fund of the Leibniz Association.

Conflicts of Interest: The authors declare no conflict of interest. The funders had no role in the design of the study; in the collection, analyses, or interpretation of data; in the writing of the manuscript, or in the decision to publish the results. 


\section{References}

1. FAO Food Outlook-Biannual Report on Global Food Markets. Available online: http://www.fao.org3ca4526enca4526en.pdf (accessed on 18 September 2019).

2. IRRI By-products. International Rice Research Institute (IRRI) Rice Knowledge Bank. Available online: http://www. knowledgebank (accessed on 17 January 2020).

3. Contreras, L.M. Digestión Anaerobia de Residuos de la Agroindustria Arrocera Cubana Para la Producción de Biogás [Anaerobic Digestion of Residues from Rice Agro-Industry Residues for Biogas Production]. Ph.D.Thesis, Universidad Central “Marta Abreu", de Las Villas, Santa Clara, Cuba, 2013.

4. Liu, Q.; Pan, S.; Long, Z.; Li, Z.; Du, L.; Wei, Y. Assessment of Fresh and Dry Rice Straw for Biogas Potential by Anaerobic Digestion. Bioenerg. Res. 2020, 13, 845-852. [CrossRef]

5. Mofijur, M.; Mahlia, T.M.I.; Logeswaran, J.; Anwar, M.; Silitonga, A.S.; Rahman, S.M.A.; Shamsuddin, A.H. Potential of Rice Industry Biomass as a Renewable Energy Source. Energies 2019, 12, 4116. [CrossRef]

6. Contreras, L.M.; Schelle, H.; Sebrango, C.R.; Pereda, I. Methane potential and biodegradability of rice straw, rice husk and rice residues from the drying process. Water Sci. Technol. 2012, 65, 1142-1149. [CrossRef]

7. Abraham, A.; Mathew, A.K.; Park, H.; Choi, O.; Sindhu, R.; Parameswaran, B.; Pandey, A.; Park, J.H.; Sang, B.-I. Pretreatment strategies for enhanced biogas production from lignocellulosic biomass. Bioresour. Technol. 2020, 301, 122725. [CrossRef]

8. Hernández-Beltrán, J.U.; Hernández-De Lira, I.O.; Cruz-Santos, M.M.; Saucedo-Luevanos, A.; Hernández-Terán, F.; Balagurusamy, N. Insight into Pretreatment Methods of Lignocellulosic Biomass to Increase Biogas Yield: Current State, Challenges, and Opportunities. Appl. Sci. 2019, 9, 3721. [CrossRef]

9. Ahmad, F.; Silva, E.L.; Varesche, M.B.A. Hydrothermal processing of biomass for anaerobic digestion-A review. Renew. Sust. Energ. Rev. 2018, 98, 108-124. [CrossRef]

10. Nitsos, C.K.; Matis, K.A.; Triantafyllidis, K.S. Optimization of Hydrothermal Pretreatment of Lignocellulosic Biomass in the Bioethanol Production Process. ChemSusChem 2013, 6, 110-122. [CrossRef]

11. Fernandez-Cegri, V.; De la Rubia, M.A.; Raposo, F.; Borja, R. Effect of hydrothermal pretreatment of sunflower oil cake on biomethane potential focusing on fibre composition. Bioresour. Technol. 2012, 123, 424-429. [CrossRef] [PubMed]

12. López González, L.M.; Pereda Reyes, I.; Dewulf, J.; Budde, J.; Heiermann, M.; Vervaeren, H. Effect of liquid hot water pretreatment on sugarcane press mud methane yield. Bioresour. Technol. 2014, 169, 284-290. [CrossRef]

13. Garrote, G.; Domínguez, H.; Parajó, C. Hydrothermal processing of lignocellulosic materials. Holz. Als. Roh. Werkst. 1999, 57, 191-202. [CrossRef]

14. Wang, H.-Y.; Qian, H.; Yao, W.-R. Melanoidins produced by the Maillard reaction: Structure and biological activity. Food Chem. 2011, 128, 573-584. [CrossRef]

15. Zhang, D.; Feng, Y.; Huang, H.; Khunjar, W.; Wang, Z.-W. Recalcitrant dissolved organic nitrogen formation in thermal hydrolysis pretreatment of municipal sludge. Environ. Int. 2020, 138, 105629. [CrossRef]

16. Antwi, E.; Engler, N.; Nelles, M.; Schüch, A. Anaerobic digestion and the effect of hydrothermal pretreatment on the biogas yield of cocoa pods residues. Waste Manag. 2019, 88, 131-140. [CrossRef]

17. Ziemiński, K.; Romanowska, I.; Kowalska-Wentel, M.; Cyran, M. Effects of hydrothermal pretreatment of sugar beet pulp for methane production. Bioresour. Technol. 2014, 166, 187-193. [CrossRef]

18. Wang, D.; Shen, F.; Yang, G.; Zhang, Y.; Deng, S.; Zhang, J.; Zeng, Y.; Luo, T.; Mei, Z. Can hydrothermal pretreatment improve anaerobic digestion for biogas from lignocellulosic biomass? Bioresour. Technol. 2018, 249, 117-124. [CrossRef]

19. Budde, J.; Heiermann, M.; Suárez-Quiñones, T.; Plöchl, M. Effects of thermobarical pretreatment of cattle waste as feedstock for anaerobic digestion. Waste Manag. 2014, 34, 522-529. [CrossRef] [PubMed]

20. Park, S.; Yoon, Y.-M.; Han, S.K.; Kim, D.; Kim, H. Effect of hydrothermal pre-treatment (HTP) on poultry slaughterhouse waste (PSW) sludge for the enhancement of the solubilization, physical properties, and biogas production through anaerobic digestion. Waste Manag. 2017, 64, 327-332. [CrossRef] [PubMed]

21. VDLUFA. Bestimmung von flüchtigen stickstoffhaltigen Basen B. Durch Destillation. In Die chemische Untersuchung von Futtermitteln, Methodenbuch Band III [Determination of volatile nitrogenous bases B. By distillation. In The Chemical Analysis of Feed, Method Book, 3rd ed.; VDLUFA: Darmstadt, Germany, 2006.

22. Van Soest, P.; Robertson, J.; Lewis, B. Methods for dietary fiber, neutral detergent fiber, and nonstarch polysaccharides in relation to animal nutrition. J. Dairy Sci. 1991, 74, 3583-3597. [CrossRef]

23. Kaplonek, W.; Nadolny, K. Advanced Desktop SEM Used for Measurement and Analysis of The Abrasive Tool's Active Surface. Acta Microsc. 2013, 22, 278-288.

24. Wirth, B.; Krebs, M.; Andert, J. Anaerobic degradation of increased phenol concentrations in batch assays. Environ. Sci. Pollut. Res. 2015, 22, 19048-19059. [CrossRef]

25. Overend, R.P.; Chornet, E. Fractionation of lignocellulosics by steam-aqueous pretreatments. Philos. Trans. R. Soc. Lond. A 1987, 321, 526-533.

26. VDI. Standard Procedures 4630. Fermentation of Organic Materials. Characterisation of the Substrates, Sampling, Collection of Material Data, Fermentation Tests; Verein Deutscher Ingenieure. Beuth Verlag: Berlin, Germany, 2006.

27. Buswell, A.M.; Mueller, H.F. Mechanism of Methane Fermentation. Ind. Eng. Chem. 1952, 44, 550-552. [CrossRef]

28. O'Rourke, J.T. Kinetics of Anaerobic Treatment at Reduced Temperatures. Ph.D. Thesis, Stanford University, Stanford, CA, USA, 1968. 
29. Park, B.-D.; Wi, S.G.; Lee, K.H.; Singh, A.P.; Yoon, T.-H.; Kim, Y.S. Characterization of anatomical features and silica distribution in rice husk using microscopic and micro-analytical techniques. Biomass Bioenergy 2003, 25, 319-327. [CrossRef]

30. Wu, J.; Elliston, A.; Le Gall, G.; Colquhoun, I.J.; Collins, S.R.A.; Wood, I.P.; Dicks, J.; Roberts, I.N.; Waldron, K.W. Optimising conditions for bioethanol production from rice husk and rice straw: Effects of pre-treatment on liquor composition and fermentation inhibitors. Biotechnol. Biofuels 2018, 11, 62. [CrossRef] [PubMed]

31. Yu, G.; Yano, S.; Inoue, H.; Inoue, S.; Endo, T.; Sawayama, S. Pretreatment of Rice Straw by a Hot-Compressed Water Process for Enzymatic Hydrolysis. Appl. Biochem. Biotech. 2010, 160, 539-551. [CrossRef] [PubMed]

32. Monlau, F.; Trably, E.; Barakat, A.; Quemeneur, M.; Steyer, J.P.; Carrère, H. Do by-products of thermochemical treatment of lignocellulosic materials inhibit anaerobic mixed cultures?. Overview of recent findings. In Proceedings of the 13th World Congress on Anaerobic Digestion. Recovering (bio) Resources for the World, Santiago de Compostela, España, 25-28 June 2013.

33. Fijalkowski, M.; Adach, K.; Petráň, A.; Kroisová, D. Rice Husks-Structure, Composition and Possibility of Use them at Surface Treatment. Mater. Sci. Forum. 2016, 844, 153-156. [CrossRef]

34. Ang, T.N.; Ngoh, G.C.; Chua, A.S.M. Comparative study of various pretreatment reagents on rice husk and structural changes assessment of the optimized pretreated rice husk. Bioresour. Technol. 2013, 135, 116-119. [CrossRef]

35. Ang, T.N.; Ngoh, G.; Chua, A.; Lee, M. Elucidation of the effect of ionic liquid pretreatment on rice husk via structural analyses. Biotechnol. Biofuels 2012, 5, 67. [CrossRef]

36. Ullah, Z.; Man, Z.; Khan, A.S.; Muhammad, N.; Mahmood, H.; Ben Ghanem, O.; Ahmad, P.; Hassan Shah, M.-U.; Mamoon Ur, R.; Raheel, M. Extraction of valuable chemicals from sustainable rice husk waste using ultrasonic assisted ionic liquids technology. J. Clean. Prod. 2019, 220, 620-629. [CrossRef]

37. Angelidaki, I.; Sanders, W. Assessment of the anaerobic biodegradability of macropollutants. Rev. Environ. Sci. Biotechnol. 2004, 3, 117-129. [CrossRef]

38. Rajput, A.A.; Zeshan; Visvanathan, C. Effect of thermal pretreatment on chemical composition, physical structure and biogas production kinetics of wheat straw. J. Envrion. Manag. 2018, 221, 45-52. [CrossRef] [PubMed]

39. Shang, G.; Zhang, C.; Wang, F.; Qiu, L.; Guo, X.; Xu, F. Liquid hot water pretreatment to enhance the anaerobic digestion of wheat straw-effects of temperature and retention time. Env. Sci. Pollut. Res. Int. 2019, 26, 29424-29434. [CrossRef] [PubMed]

40. Luo, T.; Huang, H.; Mei, Z.; Shen, F.; Ge, Y.; Hu, G.; Meng, X. Hydrothermal pretreatment of rice straw at relatively lower temperature to improve biogas production via anaerobic digestion. Chin. Chem. Lett. 2019, 30, 1219-1223. [CrossRef]

41. He, L.; Huang, H.; Zhang, Z.; Lei, Z.; Lin, B.-L. Energy Recovery from Rice Straw through Hydrothermal Pretreatment and Subsequent Biomethane Production. Energ. Fuel 2017, 31, 10850-10857. [CrossRef]

42. Jiang, D.; Ge, X.; Zhang, Q.; Li, Y. Comparison of liquid hot water and alkaline pretreatments of giant reed for improved enzymatic digestibility and biogas energy production. Bioresour. Technol. 2016, 216, 60-68. [CrossRef]

43. Di Girolamo, G.; Grigatti, M.; Barbanti, L.; Angelidaki, I. Effects of hydrothermal pre-treatments on Giant reed (Arundo donax) methane yield. Bioresour. Technol. 2013, 147, 152-159. [CrossRef]

44. Kafle, G.K.; Chen, L. Comparison on batch anaerobic digestion of five different livestock manures and prediction of biochemical methane potential (BMP) using different statistical models. Waste Manag. 2016, 48, 492-502. [CrossRef]

45. Chun, J.; Lee, J.H. Recent Progress on the Development of Engineered Silica Particles Derived from Rice Husk. Sustainability 2020, 12, 10683. [CrossRef]

46. Mirmohamadsadeghi, S.; Karimi, K. Energy Recovery Together with Amorphous Nanosilica Production from Rice Straw via Dry Anarobic Digestion. Bioresources 2018, 13, 1872-1884. [CrossRef] 